\title{
The King Who Loves Sex: The Functions of Literature in Traditional Malay Poetry
}

\author{
Rahimah Hamdan
}

\begin{abstract}
For the traditional Malay society, it is taboo to talk openly about sexuality. This is due to the perception that literary works that incorporate elements of sexuality will be criticised as weak and inferior work coming from an author with bad morals and character. Furthermore, the traditional Malay authors wrote at the request of the king. Hence, all that was written had to exalt the status of the king as the sovereign ruler. The works should be rich in 'character', so as to consolidate the integration of intellectual, epistemological and cultural values for the moral benefit of the community. However, in examining the literary genre of Hikayat such as Syair Seratus Siti, it has been found that these works include so many elements of sexuality that they indirectly reflect a gender system that was supported by the society. Using Braginsky's (2001) perspective about the function of literature, this study will weave together two literary functions for entertainment and instruction at the same time. This means that elements of 'sexuality' (entertainment) must be synthesized with teaching functions for the benefit of the audience. The results show that Syair Seratus Siti successfully exploited those functions to the extent that they submerged the elements of sexuality that were reflected by the author from the start.
\end{abstract}

Index Terms-Gender, Malay, traditional, sexuality.

\section{INTRODUCTION}

The Malay community considers expressions of sexuality in literary works as 'uncivilized', especially since the traditional Malay society defines 'sexuality' as a very private, personal or taboo subject that shouldn't be openly discussed. Although elements of sexuality were first used in oral literature, such as Malay poems and proverbs, however to express these elements in written literature is considered as a violation of the conventions that are held by the Malay-Muslim community.

A review of the written conventions of traditional Malay literature revealed that standard literature was allowed to have elements of sexuality [1]. This phenomenon was not considered as 'deviant' because this genre had Hindu-Javanese influences that allowed the inclusion of these elements [2], [3]. Therefore, some episodes that encompassed the sexual experiences of the community were included in this genre like the first night, and kissing episodes leading to the arousal of the opposite sex (gay and lesbian) were romantically depicted

in these works. This was due to the importance of sexual

Manuscript received November 6, 2013; revised January 10, 2014. This work is supported by Universiti Putra Malaysia under the Research University Grant (RUGS).

Rahimah Hamdan is with the Department of Malay Language, Faculty of Modern Languages and Communication, Universiti Putra Malaysia, 43400 UPM Serdang, Selangor, Malaysia (e-mail: rahimahhamdan@gmail.com). relationships in human life at that time until it was considered as a normal culture as written in the Javanese manuscript, Serat Centhini. Furthermore, the practise of Shivaism (Hindu-Buddhist) by the people of Central and East Java who believed in the pre-Vedantic Tantric concept since the 8th century A.D. also influenced the nature of their sexuality. For them, "[...] Sex was not against religion, then for sex was religion" [4].

The question is how did the authors, with all their creativity, insert sexual elements to fulfil the functions of Malay Literature? How did the authors discuss these elements prudently while keeping to the traditional Malay conventions? Accordingly, this study will use a syair (poem) from the genre of Hikayat Literature, i.e. Syair Seratus Siti, which very clearly illustrates that element. This study will analyse how this element was so interestingly composed in this work that it fulfilled the literary functions of entertainment and instruction for the benefit of its audience [5].

\section{The Creation of Malay Gender And Sexuality}

History has proven that elements of sexuality have existed since the early stages of human beliefs and culture. The people of Pulau Seram Tengah, Maluku connected this universal cosmological process with the 'union' of two elements, symbolising the male and the female, to produce a variety of living things such as plants, animals and human beings [6]. Early written documents about the nature of sexuality in the Southeast Asian community were gathered by an Italian adventurer, Antonio Pigafetta, based on his adventures with Ferdinand Magellan in tracing the path to the 'Spice Islands' until their group arrived at Zzubu Island (Subu) [7]. The native community in Zzubu was obviously far removed from the world of human civilization, but they had a unique knowledge about genital care to maintain the elements of sex and sexuality. In this amazing community, the males who only wore palm leaves to cover their genitals, managed to invent a tool to enhance their sexual level. This special tool, which was designed to control their level of sexual satisfaction (orgasm), involved the use of a pin (made of gold or tin) which was pierced into the male genitalia (bar or penile mutilation).

It can be said that the creation of gender was different according to societies across geographical and historical spaces. Several other factors such as the spread of modernization, the emphasis on religion, customs and culture have contributed to the formation of female and male attributes in a society that conforms to the set moulds, norms and codes of gender [8], [9]. For example, women in the Southeast Asian region are more tightly bound to gender 
codes than women in the West. This means that as long as there is a clear division between the domestic and public space within a community, then women will continue to be under patriarchal domination in which all power is in the hands of the men as the heads [10].

Initially, 'gender' was known as a 'sociological study of women' [11]. The term 'gender' was used for the first time by Ann Oakley in 1972 to differentiate between 'sex' and 'gender'. According to her, 'sex' refers to the biological differences between men and women while 'gender' has to do with the culture, that is the social classification that determines the 'manliness' and 'femininity' of an individual [12]. Meanwhile, 'sexuality' is a form of power created by the gender system of society to legitimize male dominance and the oppression of women [13]. The belief in the patriarchal system has widened the gender gap in society to produce a 'binary opposition', which is a counter argument between men and women, where women are considered as 'second class' citizens. Arising from the basic biology of human beings, women are considered as being connected to nature and men are seen as the determinants of human civilization [14]. As such, 'sexuality' has much to do with male domination, which has led to the creation of the patriarchal system whereby the making of gender and sexuality are more to indulge the passions, pleasures and fantasies of men [15]. This is because it is the gender system in the society that creates gender roles and gender stereotypes, thereby leading to the formation of sexuality.

Islam, which has been professed by the Malay community since the $7^{\text {th }}$ century A.D., is a religion that honours the status of women. Several chapters in the Quran such as Surah an-Nisa', an-Nur and several others express the concern of Islam for women. Islam sees men and women as complementing one another [16]. Because of the special position accorded to women in Islam, men have been given the right to act as the protector and guardian of these women [17]. For example, the honour of women as mothers and wives, with their natural tenderness and love, require the men to be watchful in protecting their purity and chastity. However, the culture of the society has transformed this perception into a scheme whereby women are regarded as weak, passive, submissive and irrational people who need the help of the men in their every act and deed. This phenomenon has indirectly given rise to the patriarchal hegemony that legitimises the position of men as holding all power while the women continue to suffer discrimination in life. As stated by . Ahmad Shehu Abdulssalam [18] as follows:

'As a social phenomenon, religion exercises great influence on social practice where natural gender identity and sexuality are concerned. While some traditional religions have little difficulty in adjusting to social changes, Islam has aimed at guiding changes in gender relationship and human sexuality'.

The -Quran through surah al-Baqarah and al-Nur [19], touch on the importance of controlling human passions (al-Nafs) in life. The ability to control 'al-Nafs' can guide mankind towards a moral and harmonious life [20]. As such, there are 27 verses in the Quran concerning adultery, which is viewed seriously by Islam as a failure to control one's lust (lawammah), thus giving rise to several other social diseases [21] as above:
'Islam remains violently hostile to all other ways of realizing sexual desire, which are regarded as unnatural purely and simply because they run counter to the antithetical harmony of the sexes; they violate the harmony of life; they plunge man into ambiguity; they violate the very architectonics of the cosmos. As a result the divine curse embrace both the boyish woman and the effeminate man, male and female homophilia, auto-eroticism, zoophilia, etc. Indeed all these 'deviations' involve the same refusal to accept the sexed body and to assume the female or male condition. Sexual deviation is a revolt against God'.

For example, the Malay community places great importance on a girl's 'virginity', as the family's honour hinges on it. Failure to protect that 'virginity' before marriage (fornication) will result in the woman being treated like worthless 'rubbish' or 'dirt', while the man who ravaged her escapes scot free. Western scholars such as Sigmund Freud view the 'penis' as a symbol of human 'power and creativity'. It is this andro-centric hegemony that continues to place power in the hands of men as the most powerful creatures in the gender system of the society. For this reason, the Malays are very protective of their daughters and have relegated them to the domestic domain with no freedom to move into the public space. Street women or prostitutes are held in contempt by the Malay society with regard to their work and their reputation. Here the gender and sexuality of the Malays are apparent, where the society only focuses on the worth of a woman who prostitutes herself without, at the same time, measuring the worth of the man who violates her. The woman will continue to be humiliated while the man is free to indulge his lustful passion without having to face the appropriate social punishment. Such is the low status of women who prostitute themselves until they are considered to be one of the major causes for the social and moral decline of the society. This social disease can give rise to several other problems such as the dumping of illegitimate children, sexually transmitted diseases, the collapse of the family institution, and can even lead to murder due to uncontrolled passions.

A study of the Malay society also revealed that certain terms are used to clarify gender in the society. For example, the use of the term 'jantan' (male-masculine) and 'betina' (female-feminine) is a clear indication of binary-opposition between both sexes. 'Jantan' gives the connotation of strength and courage that must be possessed by every man in determining the scale of his manhood, while 'betina' only conveys a negative perception of women. This means women who are called 'betina' are women who are living in a sexually negative manner, that is who are violating or avoiding the social norms prescribed by the society. This phenomenon explains the opposing relationship that exists within the meaning of sexuality concerning men and women in the Malay community. For example, men are encouraged to have a strong sexual drive, while women who have a strong sexual drive (eroticism) will be despised and treated with contempt by their community [22].

\section{SEXUALITY: ENTERTAINMENT OR INSTRUCTION}

The portrayal of sexuality issues in a literary work is related to the agenda of the author. For the modern genre of writings, this issue can be accepted as the 'spice' that adds 
flavour to the complexity and composition of the story's plot [23]. However, for the traditional Malay society, the explicit sharing of sexuality issues with the audience remains taboo. The society cannot accept works that reflect the dominance of this issue above the actual functions of literature, which are to entertain and to instruct, especially if this issue goes against the aims of writing, which should be to advance elements of 'courtesy' in the works as stated by Tope [24] as follows:

[...] there is relative silence on the invisible aspects such as sexuality. To begin with, sexuality has a confidential, secret nature that keeps it invisible. This invisibility is usually personal in nature. In traditional Malay societies, it is a topic generally avoided, elided or often dismissed as a non-issue. Regarded as a taboo subject, or a necessary evil at best, sexuality seems to be regarded as a discomfiting, discomforting, do-we-have-to-talk-about-it topic meant for hushed whispers or instant dismissals'.

For traditional Malay society, the best literary work is one that is able to balance the concept of intelligence and character in accordance with the connotations of 'literature' as 'artistic and useful works' other than as 'magnificently descriptive essays'. 'Budi', which is derived from Sanskrit, is defined as 'common sense, wisdom; moral behaviour, manners, conduct; virtues, good deeds, charity; discretion, endurance [25]. So the best work is one that conveys 'character' to its audience [26]. A person who is 'careful', but allows his emotions to get the better of him, may end up being labelled as 'rude' by society. Furthermore, if the 'intellect' is associated with the cognitive process (left side of the human brain), then 'character' is the nature of consciousness which balances and unites the intellect, the epistemological values and the culture for the good of the society's character [27].

Braginsky was of the opinion that the actual function of literature was as ' $a$ transmitter of correctly actualised behavioural patterns' [28]. The entertainment function of literature must be combined with the instruction function in order to produce a perfect form of culture [29]. A smart author must conform to literary conventions and must especially be able to gain the recognition of the ruler as the patron of literary works. This means that if an element of 'sexuality' is inserted by the author as entertainment that can beautify the work (sphere of beauty), the element must be synthesized with the instruction function so that the audience will be able to experience the written work in their souls (perception of the carnal soul) [29]. Accordingly, this study will use data from Syair Seratus Siti under the genre of Hikayat Literature to see how this work utilizes both functions to submerge the elements of 'sexuality', which are reflected by the author from the outset.

\section{IV. 'HERo IN THE BED': AN ANALYSIS OF SYAIR SERATUS SitI}

Poem number (MS.26) is a poem from the literary genre of Hikayat Literature which was composed during the $18^{\text {th }}$ century A.D. [30]. This poem is about Sultan Mansur who was a womaniser until all six of his wives died trying to suppress their feelings. This study will demonstrate the intellectual capacity of the Malay author in balancing the elements of sexuality as entertainment and instruction so that the work could be accepted by the society. The portrayal of gender stereotypes caused men and women to be placed in certain moulds by the society. This indirectly strengthened the institution of the traditional Malay family, which promoted the patriarchal system.

\section{A. Women as Wives}

As a wife, the Malay woman has to fit the character that has been determined by the culture and society. In the traditional Malay society, a wife is subject to her husband and has to accept whatever is done to her by the husband without question or protest. This was what happened to Sultan Mansur's wives, who eventually died from depression because their husband continued to visit his concubines even though he was already married, as given below:

- Alone she sat in silence.

- Bearing her feelings day after day.

- Until she herself became lean.

- With her rivals seen to the right and left.

- Duduklah ia berdiam diri.

- Menahan hati sehari-hari.

- Sehingga kurus dengan diri.

- Madu dipandang kanan dan kiri.

As a wife, the Malay woman has to always delight her husband and suppress her own feelings. For example, the character, the Royal Princess Jumjum Maya, had to hide her feelings and learn to like her husband's 'favourites', his concubines. The phrase 'cutting flowers' in the poem is used instead of 'plucking flowers' to clearly show the 'fury' of the princess in having to please her husband. This behaviour was probably 'hypocritical' but in a traditional Malay society that supported the patriarchal system the women had to be smart in handling any test involving feelings. Like a blessing in disguise, Princess Jumjum Maya shouldered her responsibilities as follows:

- To her handmaiden the princess said.

- Summon a hundred young Sitis.

- Invite them to play in the garden.

- Cutting flowers wherever they may be.

- Kepada dayang puteri bersabda.

- Panggil seratus Siti yang muda.

- Ajak bermain ke taman syahda.

- Memenggal bunga-bungaan mana yang ada.

Wives also had to be wise in understanding the 'inner desires' of their husbands. Princess Jumjum Maya, as the intelligent character (compared to Sultan Mansur's other wives) tried to understand her husband's inner longing by allowing him to continue visiting his concubines. Despite the fact that she was heartbroken, Princess Jumjum Maya was so good at hiding her emotions that Sultan Mansur never suspected a thing. This was the gender stereotype that had to be faced by the traditional Malay women, who had to faithfully serve their husbands. Indirectly, Sultan Mansur grew to love Princess Jumjum Maya even more because of 
her great understanding of a man's biological and sexual needs.

\section{B. Women as Concubines}

In traditional society, the title 'concubine' refers to 'the mistress of the king'; whose presence was acknowledged by everyone in the palace. She was also known as the 'wife of spells' or 'wife of darkness'. As they were not legally married, they were 'kept' by the king and they served to satisfy the sexual desires of the king or the man who 'kept' them. This poem listed as many as one hundred maidens named 'Siti' from every nook and cranny of the state who were assigned to the palace as the king's (Sultan Mansur) 'companions'. Unlike the modern day 'mistress', whose identity is unknown, in the traditional royal society, the identity of the concubine was no secret and in fact this 'concubine institution' played an important role in the social agenda of the palace. In return for choosing to fulfil the sexual demands of their 'keeper', these concubines enjoyed special privileges in the palace. They gained prestige because of their duties and were held in high regard by those in the palace. This phenomenon indirectly demonstrated how the harmony in the realm depended upon the health and happiness of the king as the ruler. Therefore, meeting the sexual drives of the king was greatly emphasized, as the continued happiness of the ruler would in turn have an impact on his kingdom. Thus, the concubine system was accepted by traditional Malay society as something that did not violate the customs and culture and especially the norms of the Malays because of its impact on the reigning king. The verses below describe the privileges of the concubines in Syair Seratus Siti, which led to a competition with the queen for love and affection:

- Three months of courtship.

- Rejoicing with the princess.

- Now comes the time to grieve.

- Back to the concubines for the 'inhuman' king.

- Tiga bulan berkasih-kasihan.

- Dengan puteri bersuka-sukaan.

- Datanglah masa beroleh kedukaan.

- Kepada gundiknya baginda nan haiwan.

- A hundred Sitis were drawn together.

- Were taken by the king for a stroll.

- More of the old behaviour.

- Going together to all places.

- Siti seratus dibawa bersama.

- Dibawa baginda bercengkerama.

- Terlebih pada laku yang lama.

- Barang ke mana bersama-sama.

\section{Men as Husbands}

The gender system in the society gave the husband the 'power' (authority) to make his own arrangements to meet his physical, emotional and inner needs. Putting aside the fact that Sultan Mansur was a ruler and looking at it only from the perspective of 'men', this proves that the gender system benefitted the men in many ways. Gender stereotyping gave a man the authority to choose his own concubines and wives. In addition, to fulfil the demands of his ego and libido, Sultan
Mansur continued to take wives for himself even though he knew that his previous wives had died of a broken heart because he was more interested in his concubines than in them. For him, the ego of a man must be fulfilled and the reason why his wives died was because they failed to control their emotions, thus causing heartache to themselves. Disregarding the reason for the deaths of his wives, Sultan Mansur continued to test the patience of his wives, including that of his youngest wife, the Royal Princess Jumjum Maya. Indirectly, this demonstrated the stereotypical male dominance in testing and playing with the feelings of women as wives for the sake of satisfying their sexual dreams without being able to understand the stress that these women were undergoing, as seen in this excerpt:

- The princess was wise and so he wanted to test her.

- Thus she did all he wanted her to.

- Drunkenly crooning to his concubines.

- Happily playing around with them.

- Bijaknya puteri hendak dicubanya.

- Maka diperbuat sebarang lakunya.

- Mabuk berulit dengan gundiknya.

- Bermain-main dengan sukanya.

- Along comes Sultan Mansur inattentive.

- Drunk with laps and strokes.

- Precious to him are his one hundred Sitis.

- While his wives go about neglected.

- Sultan Mansur datanglah lalai.

- Mabuk dengan pangku dan belai.

- Siti seratus juga dinilai.

- Isterinya dihalai-balai.

\section{SEXUALITY: EXPLICIT AND IMPLICIT}

In accordance with the concept of 'literature' as an element to trigger the 'mind' and the 'character' of its audience, several elements of sexuality are beautifully worked on by the author.

\section{A. Hundred Rooms and Carved Dragons}

The construction of a hundred rooms in the palace in the early stages reflected Sultan Mansur's sexual agenda, which was disguised behind his noble character. As the king was a bachelor, it would have been no surprise if the rooms were occupied by concubines to fulfil the demands of his libido. Furthermore, there was a carving of a 'creeping dragon' on every room door symbolising the genitals, virility, strength, grandeur and greatness of a ruler. For example, Tuhfat al-Nafis relates the tale of the Bugis King who meddled in the politics of Johor after a dream that the size and shape of his sexual organs had changed, "Opu Dahing Menambun dreamt that the penis of his brother Opu Dahing Cellak changed into a creeping dragon" [31].

The 'hundred rooms' and 'creeping dragons' actually symbolized the greatness, glory and strength of the Malay ruler named Sultan Mansur. A ruler with very little influence would not have been able to build a hundred rooms just to accommodate his concubines. Furthermore, all the surrounding states continued to send their princesses to 
marry the sultan even though they were aware of the epilogue of 'death' that awaited them after their marriage. This reflected the power of Sultan Mansur until he was feared by all the surrounding states. So, it came as no surprise that he was able to build one hundred rooms and command the nobles and the common people to surrender their maidens to be his 'companions' in the palace. Similarly, the 'creeping dragon' motif conveyed the idea of the 'power' or sexual 'virility' of the man. Thus, if the motif was carved on all the doors leading to the concubines' rooms, it meant that the rooms were only to be used for venting his lust as a test of his 'manliness', as in the following excerpt:

- Rooms with walls of crystal glass.

- In alternating strips of gold.

- Doors carved with creeping dragons.

- With eyes of diamonds like eggs.

- Bilik berdinding kaca hablur.

- Di selang-seli emas berjalur.

- Pintu bertulis naga mengulur.

- Bermata intan seperti telur.

- Find me a hundred women of good character.

- I want to have them as my companions.

- To enter this insane heart.

- So that faith can set in.

- Carikan seratus perempuan yang budiman.

- Beta nan hendak ambilkan teman.

- Dibuat penghibur hati tak siuman.

- Supaya boleh menetapkan iman.

Sultan Mansur's prowess in entertaining all his concubines in one night reveals his inner strength, which is so vital for a man. The words 'sterile' or 'impotent' in the sexual world are labels that are very much feared by men because they symbolize a lack of dignity, which is measured by their 'virility' and the sexual performance of their genitals. Therefore, the poet deliberately inserted these two elements to teach about the greatness of men, especially of kings or rulers, which is measured not only by their valour and physical strength on the battlefield, and their wisdom in governing the city, but also by their ability in maintaining their 'inner strength accordingly. Thus, the element of sexuality in Syair Seratus Siti was intended to help the audience understand that sexual satisfaction was very important to men, especially in increasing their confidence and self-esteem.

\section{B. 'Virginity' and Sexuality}

The Malay community is very conscious of the concept of the 'virginity' of their daughters before they step into marriage. This poem shows how important chastity is to a woman even if she is only to become a royal concubine. Sultan Mansur was very careful in selecting his prospective concubines because he did not want to include 'widows', even if they may have had stunning looks. He considered it more prudent to take a virgin who had never had a sexual encounter with any man, even if she was lacking in physical beauty and had a bad character, rather than to take on a widow who, it was feared, had the potential to compare her past experiences to her sexual activity with him. This would hurt his ego as a man and as a sovereign ruler. Based on this poem, the lesson from the 'virginity' element is with regard to the importance of protecting the sexuality of Malay women before marriage as 'virginity' is firmly tied to the self-esteem of the women and their families. Obviously, the Malays themselves are cynical of 'widows' because they are often thought to be unable to keep 'their sexuality' in check and can thus disrupt social harmony. The stanza from the poem below clarifies this statement:

- But don't let it be a widow.

- Whose husband was as young as her.

- Although she may be good and wise.

- I don't want her in my heart.

- $\quad$ Tetapi janganlah orang yang janda.

- $\quad$ Sudah bersuami samanya muda.

- Meskipun elok bijaknya ada.

- Beta tak gemar di dalam dada.

- Even if she doesn't look good.

- Bring her still to meet me.

- Because she is not poor.

- Nothing can happen if she is taken.

- Meskipun buruk tidak mengapa.

- Bawa juga mari hendak berjumpa.

- Kerana bukannya orang yang papa.

- Diambil pun tidak menjadi apa.

\section{The King's Lust and the People's Acceptance}

Sultan Mansur, who had strong sexual drives, took one hundred virgins named 'Siti' from every corner of the state. Not all parents willingly sent their daughters to serve in the palace because they feared that they would never see them again. Some fled into the jungle for fear that some evil would befall them for their disobedience to the king. There were also some parents who willingly sent their daughters to serve the king because their status was indirectly raised from that of the proletariat (commoners) to 'servants of the king'. A concubine was a 'servant of the king' who was given a special place in the palace for fulfilling their duties for the 'sexual gratification' of the ruling king. Thus, for the Malays, it is desirable to always obey and fulfil the demands of their ruler, no matter what those demands may be. This is consistent with the dogma of the king as the "representative of God" or the "Caliph of God in the world '. What's more, the belief in the concept of sovereignty and disloyalty, inherited from the age of Hinduism, made the king an invincible ruler possessing a holy and sacred power. Service in any form to the king was considered as matchless devotion and was a great contribution to the government. As such, the concubine institution was permitted in the traditional society even though it obviously went against the values of Islam because the society during that period was still influenced by Hindu-Buddhist practices from the $7^{\text {th }}$ century A.D. Furthermore, serving to fulfil the sexual demands of the king was held in high regard by the society because it was believed to be an extension of the concept of the king as 'God incarnate', even after they had embraced Islam. Indirectly, this poem expressed the loyalty of the people to their ruler, which would ultimately ensure the harmony of a nation [32] as follows: 
'The King, 'master of all from the highest to the lowest' was the pivot of the whole political organisation of the state, the source and sum of all authority [...] the king as Dewaraja-appeared less an administrator than a God on earth'

\section{Sexuality and the Author's Agenda}

Sexuality, as an initial theme in this poem, makes Syair Seratus Siti unique compared to other poems in traditional Malay literature. It begins with the quest for the hundred concubines, and continues with them meeting each other's sexual needs, the king's marriage to the prospective queen, the queen's death as a result of being unable to endure the pain, the continuing passion with the concubines, another marriage, the deaths continue until the king's marriage to his seventh wife, which brings an end to all the suffering and is the climax of the story. Hence, the attraction of this poem lies in the matter of the sexuality of the Malay rulers against the backdrop of the palace. At first glance, it appears to illustrate the strong sexual drive of a king who is able to handle a hundred concubines in one night alone. The descriptions "an hour in each room" and "day by day he became an animal" have excessive connotations but clearly the author wanted to introduce a new phenomenon concerning the prowess of Malay men in 'making love', where all along other authors had never dared to even mention this openly. Although on the face of it the story seems merely to discuss the sexual behaviour of the sultan, indirectly it reflects the author's courage in violating the conventions of his community by dishing out something beyond the expectations of the Malays, as follows:

- An hour in each room.

- All of them became his.

- He delighted in making his choice.

- All the Sitis were beautiful to behold.

- $\quad$ Suatu jam suatu bilik.

- Sekalian itu habis dimilik.

- Sangatlah suka baginda menilik.

- Semuanya Siti dipandang molek.

\section{E. Sexual Power and the Responsibilities of the King}

True to the function of literature as a tool to convey matters that can benefit its audience, Syair Seratus Siti also illustrates a situation where a person who gives in to the 'sexual world' can forget his true position of responsibility. Being a king at the forefront on his nation, his attitudes and behaviour should set the best example and model for his people. 'The king as the umbrella for the people' means that the king is the symbol of unity and peace in his country. But if the king begins to neglect the responsibilities entrusted to him, then it could lead to the unexpected collapse of the country at the hands of internal or external elements, for example, as what befell Sultan Perumudal Perumal in the Malay historiographical work titled Hikayat Raja Pasai. Pasai was destroyed by Majapahit because their ruler made 'sex' his main agenda until he was prepared to defile his own daughters and murdered his son who tried to stop him. Thus, this poem subtly invites its audience to have a balance between internal and external needs because failure to handle this could lead to the destruction of self and the country. The excerpt from the poem below explains how Sultan Mansur was preoccupied with his pleasure in 'women' to the detriment of his responsibilities as a ruler:

- So he played and had fun.

- Teasing and joking with his concubines.

- Day by day it went on.

- It was this that made him complacent.

- Bermainlah ia bersuka-suka.

- Dengan gundiknya bergurau jenaka.

- Sehari-hari demikian juga.

- Itulah membawa baginda nan leka.

- No one stood in the way of his desires.

- Seldom did he go down to his throne room.

- His people saw him once each Friday.

- Sitting a moment before rising to leave.

- Barang kehendaknya tiada dilarang.

- Turun ke balai baginda pun jarang.

- Se-Jumaat sekali dihadap orang.

- Duduk seketika berangkat pulang.

\section{F. Emotional Control in the Home Environment}

An interesting phenomenon in this poem is the issue of 'having mistresses' as highlighted by the author. Even though love was shared out between the queen and the concubines, who were of a different status and authority in the palace, yet the pressure was more on the queen because she was guided too much by her emotions. Furthermore, prolonged jealousy, suspicion, excessive pampering, and childish behaviour could influence the climate in the household. All those negative feelings were like toxins that could further fuel the mental confusion and lead to disturbance in the soul (schizophrenia). Accordingly, the author invites his audience to be cautious of 'jealousy', particularly 'blind jealousy', which can destroy oneself if it's not controlled by a rational mind. Childishness and pampered ways also reflect the immaturity of an individual. This is because it is vital for a wife or mother to be mentally and emotionally mature so that she will be more confident and rational in dealing with the problems of her household. An excerpt from the poem below shows the great impact that emotional stress has on the home if it is not handled properly:

- There was no joy in the heart.

- Only feelings of anger towards Siti.

- The body felt as though it was dead.

- Becoming thin as a twig for bearing the pain.

- Tiada juga terhiburnya hati.

- Rasanya geram kepada Siti.

- Rasanya badan bagikan mati.

- Kuruslah kering menahankan hati.

\section{G. The Wife's Wisdom in Addressing the Husband's Ego}

The happiness of a household depends very much on the wisdom of the wife. A wisdom that covers the emotions, the mind and the behaviour is an important yardstick of the harmony between couples. This poem features the cleverness of the Royal Princess Jumjum Maya, who is described by the poet as being not only wise in her relationship with Allah swt (hablu minnallah) but also fair in her relationship with others 
(hablu minnannas). Religion is the foundation of domestic bliss. This could be seen in the conduct of Princess Jumjum Maya, who loved to study the al Quran, always remembered God, possessed a melodious voice and was clever at poetry. In fact, this character blows away the description of women as 'hibiscus flowers' (bunga dedap), beautiful yet lacking in intelligence. The presence of Princess Jumjum Maya in the palace presented the 'One Hundred Sitis' with their greatest challenge. Princess Jumjum Maya also managed to make the concubines realise that their mistakes had caused the deaths of the previous queens. In addition, her intelligence in controlling her emotions and in not allowing herself to be carried away by her feelings resulted in her succeeding in winning back her husband to herself. The author of Syair Seratus Siti wanted to inspire women to be more proactive in handling domestic problems and not to just sit back and accept whatever their husbands did without striving to change the situation. Although the author used the 'uncontrollable libido' issue as the best agent to destroy a household, at the same time he gave the solution as 'wisdom', which is the key to every problem in life. For example, this is reflected the following verses in the poem:

- The Royal Princess Jumjum Maya.

- Never pampered herself at all.

- She forced herself to love.

- But in her heart she did not adore.

- Puteri Jumjum Maya Diraja.

- Sedikit tidak lakunya manja.

- Kasihnya itu disengaja.

- Kepada hatinya tiada terpuja.

- Whatever her husband loved.

- She did immediately and wholeheartedly.

- Attended to him while he ate and dressed.

- Prepared to enjoy the taste of his love.

- Mana yang digemarkan oleh suaminya.

- Diperbuat segera dengan sungguhnya.

- Hadir sekaliannya makan dan pakainya.

- Sedia nikmat cinta rasanya.

\section{H. Tips for a Happy Household}

This poem also gives tips to couples on how to maintain their relationship and to manage the household. This was done through the character of Johan Arifin, Princess Jumjum Maya's father, who advised his daughter:

1) To conduct herself properly and to do all things well.

2) Not to pamper the husband too much until it became childish behaviour. Furthermore, as her husband had given his heart to other women, it was only fair to put aside the pampering until the husband proved his undivided loyalty to his wife.

3) Even if the husband had shown his love for his wife, it would not be wise to trust him straightaway, but instead investigate how sincere his heart was.

The excerpt below proves that the poem contains household tips:

- Customary matters be a king.

- But don't overlook the behaviour.

- Right up to Baghdad he is prepared to go.

- But don't begin to indulge him.
- Perkara adat menjadi raja.

- Kelakuan jangan banyak disahaja.

- Sampaikan Baghdad tuan tersahaja.

- Jangan selagi berbuat manja.

- Although his love seems to be as before.

- Don't put your heart into it.

- Watch his behaviour if you want to be certain.

- Sooner or later, my child, you will see.

- Meskipun kasih dengan seperti.

- Jangan dahulu ditaruh di hati.

- Lihat lakunya supaya pasti.

- Sungguh tidaknya anakanda lihati.

The author also recorded another tip for domestic bliss and that is the presence of a child that can strengthen the bond of love between couples, especially if the husband has a 'wild' behaviour. Clearly, Sultan Mansur changed after the birth of Prince Sarif Ismail. Instead of spending his time having fun with his concubines, he switched his attention to his son that was born out of his marriage union with his dearly wife, the Royal Princess Jumjum Maya.

\section{CONCLUSION}

Hikayat Literature in traditional Malay literary genre loaded with entertainment and instruction for the audience. The inclusion of elements of 'sexuality' in literature requires creativity on the part of the author so that these elements will not tear down the 'value' of the work. Literary works will always contain 'sensible' values provided the contents abide by the conventions of the Malay audience and of the king as the patron of literary activities.

This study found that Syair Seratus Siti opened the mind of the Malay society to think about an issue that was once viewed as taboo but which had become something significant to life because that was the reality that they had to face with an open mind.

\section{REFERENCES}

[1] A. N. Farish, "What your teacher didn't tell you," The Annexe Lectures Petaling Jaya: Matahari Books, vol. 1, pp. 159-166, 2009.

[2] J. Ras, "The Panji romance and W. H. Rassers Analysis of its theme," Bijdragen tot de Taal-, Land-en Volkenkunde, Leiden, vol. 129, no. 4, pp. 411-456, 1973.

[3] W. H. Rassers, "Panji: The cultural hero," A Structural Study of Religion in Java, The Hague: Martinus Nijhoff, 1959.

[4] A. N. Farish, "What your teacher didn't tell you," The Annexe Lectures Petaling Jaya: Matahari Books, vol. 1, pp.154-155, 2009.

[5] V. I. Braginsky, The System of Classical Malay Literature, Leiden: KITLV Press, 1993; V. I. Braginsky, Yang Indah, Berfaedah dan Kamal. Sejarah Sastra Melayu dalam Abad 7-19,Jakarta: INIS, 1998; V. I. Braginsky, The Comparative Study of Traditional Asian Literatures: From Reflective Traditionalism to Neo-Traditionalism, Surrey: Curzon Press, 2001; G. L. Koster, Roaming Through Seductive Gardens: Readings in Malay Narrative, Leiden: KITLV Press, 1997.

[6] A. R. Abdullah, Falsafah Alam Semesta: Dalam Sejarah Tauhid Melayu, Petaling Jaya: Access Infotech Sdn. Bhd, 1995.

[7] A. Pigafetta, Magellan's Voyage: a Narrative Account of the First Navigation, (Trans.) R. A. Skelton, London: The Folio Society, 1975, pp. 90 .

[8] B. L. Marshall, Configuring Gender: Explorations in Theory and Politics, Peterborough, Ontario: Broadview Press, 2000.

[9] R. S. Hashim, "Meniti Duri dan Ranjau: Pembikinan Gender dan Seksualiti dalam Konteks Dunia Melayu," in Gender dan Seksualiti di 
Alam Melayu, SARI, M. Zariat, R. S. Hashim. (eds.), Jil. vol. 24, pp. 15-34, July 2006

[10] M. Z. Rosaldo et al., Woman, Culture, and Society. Stanford University Press: Stanford, California, 1974, pp. 36.

[11] A. S. Wharton, The Sociology of Gender: An Introduction to Theory and Research, Oxford: Blackwell, 2005, pp. 4.

[12] A. Oakley, Sex, Gender and Society, London: Maurice Temple Smith, 1972, pp. 16.

[13] C. MacKinnon, "Feminism, method and the state: an agenda for theory," in Feminism and Sexuality, S. Jackson, S. Scott. (eds.), Edinburgh: Edinburgh University Press, 1996, pp. 185.

[14] S. B. Ortner, "Is female to male as nature is to culture?" in Women, Culture and Society, M. Z. Rosaldo, L. Lamphere. (eds.), Stanford: Stanford University Press, 1974, pp. 73.

[15] C. MacKinnon, Towards a Feminist Theory of the State, Harvard: Harvard University Press, 1989, pp. 129.

[16] Al Quran (16:97; 2:187).

[17] Al Quran (4:44)

[18] A. S. Abdulssalam, "Gender and sexuality: an Islamic perspective," in Gender dan Seksualiti di Alam Melayu: Wacana, Tanggapan dan Manifestasi, SARI, M. Z. A. Rani, R. S. Hashim. (eds.), Jil. vol. 24, pp. 36, July 2006

[19] Al Quran (2:222; 2:187; 24:30-31; 24:2; 24:4; 24:23; 24:33).

[20] A. Bouhdiba, Sexuality in Islam, London: Routledge \& Kegan Paul, 1985, pp. 31.

[21] L. K. Hui, "Budi as the Malay mind: a philosophical study of Malay ways of reasoning and emotion in peribahasa," Ph.D. dissertation, Department of Austronesian Studies, The Asia-Africa Institute, Faculty of Oriental Studies, University of Hamburg, 2003, pp. 177-178.

[22] M. Z. A. Rani, "Seksualiti dalam novel Melayu: Satu analisis teks berdasarkan persuratan Baru," Ph.D. dissertation, Institut Alam dan Tamadun Melayu, Universiti Putra Malaysia, 2004.

[23] L. R. Tope, "The hushed identity: Malay ethnicity and sexuality in Malaysian and Singaporean literature in English," in Reading the Malay World, Hosking et al., (eds.). South Australia: Wakefield Press, 2010, pp. 100.
[24] Kuala Lumpur: Dewan Bahasa dan Pustaka, Kamus Dewan, 1986, pp. 152.

[25] G. L. Koster, Roaming through Seductive Gardens: Readings in Malay Narrative, Leiden: KITLV Press, 1997, pp. 15.

[26] L. K. Hui, "Budi as the Malay Mind: A Philosophical Study of Malay Ways of Reasoning and Emotion in Peribahasa," Ph.D. dissertation, Department of Austronesian Studies, The Asia-Africa Institute, Faculty of Oriental Studies, University of Hamburg, 2003, pp. 92.

[27] H. Ahmad and A. dan Budi, Dewan Budaya, pp. 42-43, July 2001

[28] V. I. Braginsky, The System of Classical Malay Literature, Leiden: KITLV Press, 1993; V. I. Braginsky, Yang Indah, Berfaedah dan Kamal. Sejarah Sastra Melayu dalam Abad 7-19, Jakarta: INIS, 1998 V. I. Braginsky, The Comparative Study of Traditional Asian Literatures: From Reflective Traditionalism to Neo-Traditionalism. Surrey: Curzon Press, 2001, pp. 240-241.

[29] V. I. Braginsky, The Comparative Study of Traditional Asian Literatures: From Reflective Traditionalism to Neo-Traditionalism. Surrey: Curzon Press, 2001, p. 31.

[30] J. Kasdan (ed.), Syair Seratus Siti, Kuala Lumpur: Dewan Bahasa dan Pustaka, 2004.

[31] R. A. Haji, Tuhfat al-Nafis, Kuala Lumpur: Dewan Bahasa dan Pustaka, 1998 , pp. 54

[32] G. Coedes, The Indianised States of Southeast Asia, Kuala Lumpur: University of Malaya Press, 1968, pp. 119

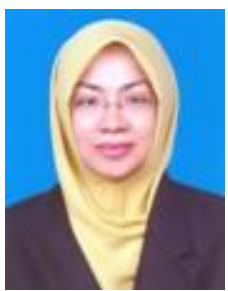

Rahimah Hamdan was born in Raub, Pahang in December 1972. She graduated with bachelor of arts and master of arts in Malay Literature from Universiti Kebangsaan Malaysia. She is currently pursuing her $\mathrm{Ph} . \mathrm{D}$. at the same university. Rahimah is presently a lecturer in Traditional Malay Literature, Malay Culture and Gender Studies at Faculty of Modern Languages and Communication, Universiti Putra Malaysia. She is also a member of IEDRC. 